\title{
Young Scientist Pioneer 2019: Evaluation of the Effectiveness of the Modules Prepared for SMK Wira Penrissen, Sarawak
}

\author{
Asraful Syifaa' Ahmad ${ }^{1, *}$, Rafidah Muhamad ${ }^{1}$, Amalina Yusup ${ }^{2}$, Nabilah Kassim³, \\ Fathiah Nabila Mohd Daud ${ }^{4}$, Muhamad Farhin Harun ${ }^{1}$, Liza Md Salleh ${ }^{5}$, D. Dahyuna \\ Mohd Yunos $^{5}$, Nursyazwani Aznan ${ }^{6}$, Rafidah Abd Rahim ${ }^{6}$, Mohd Iskandar Ishak ${ }^{7}$, \\ Filzah Hazirah Jaffar ${ }^{5}$, Nurlaila Syamsul Bahri ${ }^{5}$, Nurul Diyana Zainal ${ }^{3}$, Sarah Alia \\ Norazlan $^{2}$
}

${ }^{1}$ School School of Computing, Faculty of Engineering, Universiti Teknologi Malaysia

${ }^{2}$ Faculty of Built Environment \& Surveying, Universiti Teknologi Malaysia

${ }^{3}$ Department of Physics, Faculty of Science, Universiti Teknologi Malaysia

${ }^{4}$ Azman Hashim International Business School, Universiti Teknologi Malaysia

${ }^{5}$ School of Chemical and Energy Engineering, Universiti Teknologi Malaysia

${ }^{6}$ Deputy Vice Chancellor's Office (Research and Innovation), Universiti Teknologi Malaysia

${ }^{7}$ Deputy Vice Chancellor's Office (Student Affairs) Universiti Teknologi Malaysia

*Corresponding author. Email: asrafulsyifaa.ahmad@gmail.com

\begin{abstract}
Science, technology, engineering and math (STEM) is a new subject module to prepare the students with high skill demanded by the industry based on Malaysian Education Blueprint 2013-2025. The purpose of this study is to review and analyses the effectiveness of the modules designed for secondary schools. The program took part in SMK Wira Pensrissen, Kota Samarahan, Sarawak and involving 100 selected Form One students. The modules touched several subjects in secondary schools and aimed to gain the interest of students to learn STEM. The modules have been presented and taught in a fun way by students from multiple backgrounds of study from Universiti Teknologi Malaysia (UTM). The school students experienced the survey data before the program and after the program. The results show that student satisfaction was increasing gradually for bestmanaged modules indicating that proactive implementation of appropriate responses to student feedback on their learning journey is effective in improving both student satisfaction and learning.
\end{abstract}

Keywords: Science, Technology, Engineering, Mathematics, Education

\section{INTRODUCTION}

The term "STEM education" is now widely used, but what does it mean and how might it influence Malaysian education? Based on the observation that STEM, use as an acronym for Science, Technology, Engineering, and Mathematics education is often a term for science or mathematics, STEM should mean an increased emphasis on technology in school programs as the products of technology and engineering has so greatly influenced everyday life. A true STEM education should increase students' understanding of how things work and improve their use of technologies. STEM education should also introduce more engineering during pre-college education. The engineering is directly involved in problem solving and innovation, two popular themes with high priorities on every nation agenda [1]. Given its economic importance to society, students should learn about engineering and develop some of the skills and abilities associated with the design process. Engineering has some presence in our schools, but certainly not the amount consistent with its careers and contributions to society.

Existing approach in Malaysian Education Curriculum needs to be changed into an interdisciplinary approach called STEM curriculum to achieve 21st century skill for Malaysia context [2]. For this reason, Kolej Datin Seri Endon (KDSE), Universiti Teknologi Malaysia (UTM) student committee has chosen Sarawak as the place to conduct STEM education-related programs recently. The state government has given extra attention towards STEM as part of the school's curriculum by providing a large amount of money to set up STEM's Laboratory in six (6) schools. However, the committee has a twisted idea by choosing non-STEM-based schools such as SMK Wira Penrissen, Kota Samarahan, Sarawak as the venue of the program with the help from Universiti Malaysia Sarawak 
(UNIMAS) and Jabatan Pendidikan (JPN) Sarawak. This program has been conducted on 16th until 18th July 2019 involving 100 Form One student from and 16 facilitators. All facilitators that involved in this program come from the background of different courses. It is hoped that by having this uniqueness, the program would be different from other STEM programs as it may embed various ideas from other fields of study by creating an ingenious module for STEM.

In addition, the STEM program is parallel with Malaysia Education Blueprint 2013-2025 to prepare the student as highly skilled workers demanded by the industry. In contrast, there were only $23 \%$ of upper secondary school student studying pure science in Malaysia. Therefore, the Department of Education is now starting to offer a few STEM-based programs, including advanced research projects with a STEM emphasis while understanding nextgeneration learning technologies, STEM grant selection programs and general programs that support STEM education. Hence, investments should also be made to recruit and support STEM teachers, as well as support STEM-focused high schools with STEM innovation networks.

The aims of this program were to let the students learn science in a fun way by exposing them with nature and science in daily lives yet not too exam oriented. Meanwhile, this program is also meant to test the students' capability in higher order thinking and ensure that the modules are aligned with the school's syllabus. Other than that, this program is an initiative to introduce UTM as a prestigious university in East Malaysia while giving an opportunity for UTM's students to interact with different culture society in an attractive way.

The remainder of this paper is organized as follows: Section 2 reviewed the current issues related to the program. Followed by Section 3 that explain the methodology of the research, Section 4 discussed the results gained, and lastly, Section 5 concludes the research.

\section{BACKGROUND}

Literature review for this paper is focused on the objective for STEM education. This section discussed on the importance of STEM and current STEM application to instill STEM education approach among the school students. We also discussed our program venue which is in a school located in Sarawak on why we decide to conduct our program there.

\subsection{Science, Technology, Engineering and Mathematics (STEM)}

According to a report by the website STEMconnector.org, 2018, ("Achieving a Sustainable STEM Workforce,") a projection has estimated the need for 8.65 million workers in STEM-related jobs. The manufacturing sector faces an alarmingly 600,000 large shortage of employees with the necessary skills. In addition, based on the United Kingdom Royal Academy of Engineering report, ("A World-Leading STEM Education for All Young People Across the UK,") Germany has a shortage of 210,000 workers in mathematics, computer, natural science and technology disciplines.

STEM education focuses on the introductory level. This initial step provides standards structured enquiry and realworld problem-based learning which connects all four STEM subjects. The goal is to pique students' interest in pursuing the courses, not because they have to but more to emphasize STEM learning opportunities. Furthermore, the courses would become a more demanding and challenging middle school. At this level, the students could be guided in STEM careers related. The student will be trained to focus on the subjects' application in a challenging and rigorous manner. The courses and pathways are emphasizing on bridging between education and employment [3], [4]. This is based on the best evidence science teaching which is funded by The Salters' Institute. Best evidence science teaching (BEST) is a new assemblage of research-informed teaching and learning resources.

What makes STEM different from traditional science and math education is the blended learning environment and showing students how the scientific method could be applied to everyday life. It teaches the student computational thinking and focuses on the real-world application of problem-solving. Therefore, this program has taken this opportunity to bring forward STEM to elementary school.

There are many ways to make STEM a success. Firstly, is by developing teachers and leaders to explore programs and resources that support professional development and drive the impact of teaching across schools and colleges [5]. The collections of hand-picked resources enable them to interact with more deeply with the research findings to give new ideas and inspiration in the STEM module programs. The envisioning workforce could be a guide for best resources to support primary computing, mathematics and science aligned to the school curriculum. This guiding principle is reinforced by an inspirational idea, guidance and ready-to-use resources to help meet the teachers' standards.

Furthermore, to develop an outstanding primary science curriculum, different approaches are needed to identify learners' thinking, clarify learning goals to look into students' understanding, both in and between lessons. The curriculum and assessment should not traditionally be taught in the material area, but more to the nature surrounding. Besides, inspiring groups and communities should be developed to discover projects, activities and challenges to engage young people of all ages with the worlds to wonder of STEM subjects and careers. Consequently, this group could share ideas, stories and best practices to attract students' interest in learning STEM. For example, STEM clubs, STEM ambassadors, and STEM enrichment. This activity would allow the student to involve in exploring STEM subjects in innovative and inventive ways outside the curriculum. 
Therefore, the activity could be a great platform and an enjoyable way to engage with students.

The grand challenge to our futures is from artificial intelligence to future mobility. For instance, in the industrial strategy of engineering in computing, these showcase the areas of engineering that people can specialize in from big data to robotics. Hence, each challenge offers an opportunity to engage and inspire young people.

\subsection{Sarawak as the hub of STEM in Malaysia}

As stated in previous section, Sarawak is one the top pioneer in STEM education because of the incentive given by the government to establish STEM education program. Currently, they planning to open more STEM labs across the country as current built lab show a very positive result among the students. Besides than established STEM lab in several school, the government of Sarawak with collaboration with UNIMAS, Sarawak Multimedia Authority (SMA) and other organizations, has successfully conducted several high impact programs related to STEM. Most notable event are STEM Playground, Karnival STEM, Young Makers Champion, Drone and Robotic Explore (Drobotex) Challenge and few others.

As one of the top local country in Malaysia that has more advanced knowledge related to STEM education, there are many knowledges can be gathered here as they successfully conducted many STEM related events with very promising output from the students. One of the focus of STEM in Sarawak is to attract younger audience to instill interest in science and technology at early stage of their education. In this way, they can be equipped with related skill and knowledge especially in this digital era where the competition is very high.

Capturing students' interest in STEM content at an earlier age, a proactive approach can ensure that students are on track through primary and secondary school to complete the needed coursework for adequate preparation to enter STEM degree programs at institutions of higher learning [6]. Hence, Sarawak is the best location to conduct our program. Besides than conducting a learning environment, our program blended the learning session with interesting experiments and engaging directly to the student. This approach also one of the basic learning sessions conducted by STEM activity which to encourage student to involve and take part during the learning session. This way, their confident level also should be increased. Early exposure to STEM also can positively impacts elementary students' views and dispositions [7], [8]. Knowledge gained during the program can be applied in other country which want to include STEM education in their school curriculum as the steppingstone to introduce their student about importance of STEM.

\section{METHODOLOGY}

The program called Young Scientist Pioneer was a program that pioneer to teach the students to learn these four cores subject (Science, Technology, Engineering and Mathematics) in a fun way. It was a two days program undertaken by 100 form one students from Sekolah Menengah Kebangsaan Wira Penrissen, Kota Samarahan, Kuching, Sarawak. Meanwhile, the facilitators were the Universiti Teknologi Malaysia (UTM) from multidiscipline background of studies. Table 1 below shows the list of facilitators according to the background of study.

Table 1 Study background of the facilitators

\begin{tabular}{|l|c|}
\hline \multicolumn{1}{|c|}{ Course } & Number of facilitators \\
\hline Science Computer & 7 \\
\hline Physics & 1 \\
\hline Civil Engineering & 1 \\
\hline Nuclear Engineering & 2 \\
\hline Chemical Engineering & 1 \\
\hline Architecture & 1 \\
\hline Science & 1 \\
\hline Business & 1 \\
\hline Total & $\mathbf{1 5}$ \\
\hline
\end{tabular}

Given the short period and the complexity of the modules, the facilitators were required to design experiments following the syllabus based, a set of understandability activity and also three (3) questions to test the understandability of students. The hands-on activity must be in a fun way and can be repeated at home. For module syllabus-based learning environment to have any possibility of inspiring a wide range of students and motivating them to take control of their learning experience then the modules needs to be designed to be flexible enough to accommodate different student interests [9]. The practical and design method of working on modules helped students to experience the real world and tackle an actual problem. It helped students to better engage in their learning process.

There were six different modules design for this program. All the modules were prepared in Bahasa Malaysia due to the language constraints in Sarawak and for a better understandability off the students. The STEM-related subjects in the secondary school curriculum are Biology, Chemistry, Physics, Science, Mathematics and Additional Mathematics. All the modules are creatively designed according to the syllabus by Malaysia Education Ministry. The modules are stated in the Table 2 below. 
Table 2. Modules designed and their description

\begin{tabular}{|c|c|}
\hline Module Title & Materials and Description \\
\hline $\begin{array}{l}\text { Algebraic } \\
\text { Expression }\end{array}$ & $\begin{array}{l}\text { - By using 'Sticky Tiles' is one of the } \\
\text { easy-to-understand and practiced } \\
\text { learning patterns in a student's } \\
\text { classroom. } \\
\text { Integers and Algebraic Expressions } \\
\text { are among the titles that can be } \\
\text { combined for learning using this } \\
\text { method. }\end{array}$ \\
\hline $\begin{array}{l}\text { Crystal } \\
\text { Snowflakes }\end{array}$ & $\begin{array}{l}\text { - This experiment will form a snow- } \\
\text { shaped crystal made from a chenille } \\
\text { craft stick. Crystals will form for a } \\
\text { minimum of } 8 \text { hours until overnight } \\
\text { and require only a few ingredients. } \\
\text { The main ingredient in this } \\
\text { experiment was Borax powder, a } \\
\text { type of compound applied as a } \\
\text { catalyst for washing clothes }\end{array}$ \\
\hline Photosynthesis & $\begin{array}{l}\text { - To study the presence of starch on } \\
\text { leaves as the presence of sunlight } \\
\text { helps plants in the process of } \\
\text { photosynthesis and starch } \\
\text { production. } \\
\text { - Use leave, tissue paper, syrup and } \\
\text { methanol }\end{array}$ \\
\hline Friction & $\begin{array}{l}\text { - Frictional force is the force } \\
\text { produced when two surfaces come } \\
\text { into contact with each other and } \\
\text { friction force is the force that } \\
\text { opposes, stops, and obstructs the } \\
\text { movement of an object. } \\
\text { The friction force also prevents an } \\
\text { object from moving and can causes } \\
\text { the movement of an object to slow } \\
\text { down and eventually stop. }\end{array}$ \\
\hline Oobleck & $\begin{array}{l}\text { Oobleck is a mixture that has fluid } \\
\text { and solid properties depending on } \\
\text { the force applied to the Oobleck } \\
\text { mixture. } \\
\text { If the applied force is high, Oobleck } \\
\text { will show solid properties. } \\
\text { Meanwhile, if the applied force is } \\
\text { low, the liquid characteristics are } \\
\text { shown } \\
\text { Materials are corn flour, water and } \\
\text { food coloring. }\end{array}$ \\
\hline $\begin{array}{l}\text { Plant } \\
\text { Reproduction }\end{array}$ & $\begin{array}{l}\text { The aims are to communicate the } \\
\text { structure and function of each part } \\
\text { of the flower, to learn the next } \\
\text { flowering / flowering process for } \\
\text { self-pollination and clogging. }\end{array}$ \\
\hline
\end{tabular}

In order to measure the effectiveness of this program accurately as possible, a quick quiz-based activity is conducted before and after the experiment is shown. It is called pre-quiz and post-quiz respectively. The objective of pre-quiz is to determine the level of knowledge related to each module as shown in Table 2 before the hands-on activities are shown to them by the facilitators. It is worth to mention that each experiment is constructed based on the textbook syllabus to ensure the scope of the experiment is out of the student knowledge. On the other hand, postquiz is conducted right after the hand-on activity to reevaluate student knowledge after the experiment. Hence, it has similar questions as a pre-quiz, however it is expected that students have a higher score in a post-quiz as their understanding is clearer. In order to ensure the said result is achieved, the question must be able to test the student from basic knowledge to experimental knowledge where the answer is shown by the experiment and the explanation delivered by facilitators.

\section{RESULTS AND FINDINGS}

Figure 1 shows the overall result for each station.

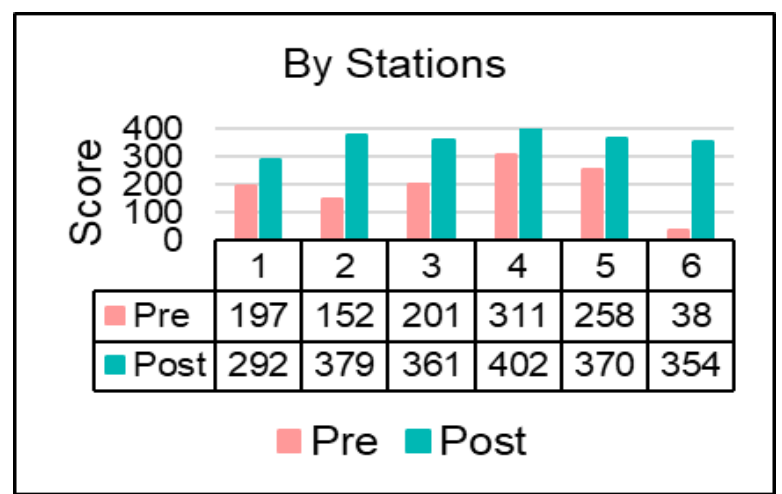

Figure 1 Bar chart for Pre-quiz and Post-quiz for Each Station

Both pre-quiz and post-quiz has five questions which total to ten points for one student. As previously mentioned, this program involves 100 students. Hence, maximum score that can be achieved for each station is 500. From the results shown in Figure 1, it can be concluded that all stations scored higher in the post-quiz than the pre-quiz. Also shown in Figure 1 that overall student already has prior basic understanding for all experiments except for Station 6 which covers plant reproduction module. This is due to the topic is yet to be covered in class as the program is held in July, which only half of their syllabus is taught in the class during this timeframe. Table 3 shows the percentage of accurate answers scored by the student for each station.

Overall, the result showed that all students score $36.6 \%$ for pre-quiz and significantly increased to $71.9 \%$ for postquiz. Station 6 has the highest incremental percentage in score which is $63.2 \%$ followed by Station 2. This result also showed that the students already have prior knowledge related to some topic which resulting the score for pre-quiz is relatively high as shown by Station 4 $(62.2 \%)$ and Station $5(51.6 \%)$. A notable topic that has 
low post-quiz score is Station 1 which is $58.4 \%$. Station 1 focus on the Algebraic Expression topic which require mathematical knowledge and very good problem-solving skill. This is the only station which covers mathematic related module. Unlike other modules which the answer is shown to them directly by experiment output or explanation delivered to them, mathematics on the other hand, requires student to derive the answer themselves based on their understanding of the experiment shown by Station 1. This skill cannot be nurtured in a short period of time, but as the score is increased, we can conclude that there is an improvement in their mathematical skill after the experiment.

Table 3. Detailed Score Increment Obtained by each Station

\begin{tabular}{|c|c|c|c|c|c|}
\hline Stations & $\begin{array}{c}\text { Pre } \\
\text { accurate }\end{array}$ & $\begin{array}{c}\text { Post } \\
\text { accurate }\end{array}$ & $\begin{array}{c}\text { Pre } \\
\text { Score } \\
(\boldsymbol{\%})\end{array}$ & $\begin{array}{c}\text { Post } \\
\text { Score } \\
(\boldsymbol{\%})\end{array}$ & $\begin{array}{c}\text { Score } \\
\text { Increment } \\
(\boldsymbol{\%})\end{array}$ \\
\hline 1 & 197 & 292 & 39.4 & 58.4 & 19 \\
\hline 2 & 152 & 379 & 30.4 & 75.8 & 45.4 \\
\hline 3 & 201 & 361 & 40.2 & 72.2 & 32 \\
\hline 4 & 311 & 402 & 62.2 & 80.4 & 18.2 \\
\hline 5 & 258 & 370 & 51.6 & 74 & 22.4 \\
\hline 6 & 38 & 354 & 7.6 & 70.8 & 63.2 \\
\hline Total & $\mathbf{1 1 5 7}$ & $\mathbf{2 1 5 8}$ & $\mathbf{3 8 . 6}$ & $\mathbf{7 1 . 9}$ & $\mathbf{3 3 . 4}$ \\
\hline
\end{tabular}

Finally, the overall result showed that our program achieved its objective. It is because hand-on activity which includes various short experiments, fun learning environment and two-ways communication between students and facilitator. It is a very challenging task for the facilitators to tone down the learning transfer activity so that any scientific knowledge can be understood by secondary school level student. Transforming the knowledge in various kind of simpler form such as visualization, analogy and hand-on provide more engaging learning process and helps the student understand more about the related subject. The result also showed that our modules are effective and has a very good impact to the student as they can understand and perform well in each station during post-quiz activity.

\section{CONCLUSION}

As a conclusion, this study is expected to aid the authorities in several features such as to determine which specific subject contribute most to the student academic performance especially subjects that related to STEM. Hence, it also can be used to distinguish subject that most student cannot perform well in their school. In order to increase the student performance, school can plan more interesting activities that can attract the student toward the subject and increase their understanding for that specific subject. From this study, the we can see the pattern where student understanding for specific subject significantly increase when they are study in a more fun and engaging activity. This can invoke the student interest, motivating them and cultivate 'culture of asking' among the students. The Young Scientist Pioneer Program is expected to be a catalyst for STEM students. The collaboration between universities, schools and other teachers also provide opportunities for UTM students to develop communication skills, leadership skills and thinking skills. For future works, the reliability of the effectiveness will be test in order to strengthen the results.

\section{ACKNOWLEDGMENT}

The authors would like to express their appreciation for the support of Kolej Datin Seri Endon, Universiti Teknologi Malaysia, Tourism Malaysia, SMK Wira Penrissen, Kota Samarahan, Jabatan Pendidikan Negeri Sarawak, Sarawak state assemblyman (Parlimen and ADUN Negeri) for the program facilities and financial support.

\section{REFERENCES}

[1] W. Christopher, L. Jim, and W. Mary, "Ready to Innovate: Are Educators and Executives Aligned on the Creative Readiness of the U.S. Workforce?," Challenge, p. 20, 2008, Accessed: Jun. 28, 2020. [Online]. Available: www.conference-board.org.

[2] K. Osman, L. C. Hiong, and R. Vebrianto, "21st Century Biology: An Interdisciplinary Approach of Biology, Technology, Engineering and Mathematics Education," Procedia - Soc. Behav. Sci., vol. 102, pp. 188-194, Nov. 2013, doi: 10.1016/j.sbspro.2013.10.732.

[3] J. H. Elaine, "What is STEM Education? | Live Science," Live Science, 2014.

https://www.livescience.com/43296-what-is-stemeducation.html (accessed Jun. 28, 2020).

[4] R. W. Bybee, "What is STEM education?," Science, vol. 329, no. 5995. p. 996, 2010, doi:

10.1126/science. 1194998 .

[5] M. Abd and H. Bunyamin, "Pendidikan STEM Bersepadu: Perspektif Global, Perkembangan Semasa di Malaysia, dan Langkah Kehadapan,” 2015. Accessed: Jun. 28, 2020. [Online]. Available: https://www.researchgate.net/publication/301567750.

[6] N. K. DeJarnette, "Implementing STEAM in the Early Childhood Classroom," Eur. J. STEM Educ., vol. 3, no. 3, 2018, doi: 10.20897/ejsteme/3878.

[7] A. Bagiati, S. Y. Yoon, D. Evangelou, A. Magana, G. Kaloustian, and J. Zhu, "The landscape of PreK-12 engineering online resources for teachers: global trends," Int. J. STEM Educ., vol. 2, no. 1, Dec. 2015, doi: 10.1186/s40594-014-0015-3. 
[8] R. W. Bybee and B. Fuchs, "Editorial - Preparing the 21st century workforce: A new reform in science and technology education," Journal of Research in Science Teaching, vol. 43, no. 4. pp. 349-352, Apr. 2006, doi: 10.1002/tea.20147.
[9] A. M. Connor, S. Karmokar, and C. Whittington, "From STEM to STEAM: Strategies for Enhancing Engineering \& Technology Education,” Int. J. Eng. Pedagog., vol. 9, no. 2, p. 137, 2019. 